\title{
Benign Soft Tissue Tumor of Uncertain Differentiation
}

National Cancer Institute

\section{Source}

National Cancer Institute. Benign Soft Tissue Tumor of Uncertain Differentiation. NCI

Thesaurus. Code C6587.

A benign soft tissue tumor in which the line of differentiation is uncertain. 